\title{
Dislocation Policies in Western Europe: Past, Present, and Future
}

\section{$B y$ THOMAS SAMUEL EBERLE}

ABSTRACT: Within the past two decades, the "brutal American management methods," which caused a national upheaval against Firestone in the 1970s, have become common practice in Swiss and other European corporations. These practices include global sourcing, dislocation of work to Third World countries, and workforce reductions by rationalization. In the middle of this general trend, Volkswagen in Germany set a countermodel: by introducing the four-day workweek, it redistributed work in the existing workforce, increased the sense of solidarity, and avoided layoffs. Volkswagen's actions added new fire to the heated European debate on how to deal with unemployment: by further deregulation or by work-time reduction and redistribution of work? In Europe, quite in contrast to the United States, an ongoing tension exists between modernization and the traditional culture, a tension manifest in a deep schism within the population.

Thomas Samuel Eberle teaches sociology at the University of St. Gallen, Switzerland. He is the former vice president of the Swiss Sociological Association and served as an editor of the association's newsletter and of its publishing company, SEISMO. His sociological practice activities include the training of managers, social workers, project managers, and others. He has written on the topics of the sociology of work, culture, communication, and methodology. 
TN 1978, when Firestone Tire and Lubber Company shut down its factory in Pratteln BL, Switzerland, laying off hundreds of workers, there was a national outcry blaming the ruthless American style of management. Thirteen years later, when the prestigious Swiss company Swissair dislocated work to a Third World country to cut costs, there was little protest. The Swiss had quickly learned to accept ferocious measures of rationalization as a means of survival in an ever more competitive world economy and to live with a formerly unknown rate of unemployment.

Can cultural brands of capitalism survive in an increasingly globalized world economy?

FIRESTONE SHUTS DOWN ITS SWISS PLANT IN 1978:

THE STORY OF A SHOWDOWN

Switzerland is a placid country with a long democratic tradition and an industrious, highly qualified workforce. The Swiss are fairly pragmatic they try to reach 'consensus rather than engage in ideological conflicts that might result in political confron tation and stalemate. This mind-set can be found in nearly all areas of their lives. On the political level, it is manifested in the federalistic structure of the nation, with 26 fairly autonomous states. It is also seen in the way all major political parties take part in the government, leaving no significant political opposition. Also, it is manifest in political referendums, where the people vote, several times per year, to accept or refuse a modification of the constitution or a specific new law proposed by the parliament. On the cultural level, the
Swiss managed to weld together four different cultures with four different languages (German, French, Italian and Rhaeto-Romansh)

On the economic level, the prag matic mentality is best expressed by the special industrial relations be tween the labor unions and the employers' association, which stand in sharp contrast to those in other European countries. There was only one general strike in the country, for five days in 1918, after World War I-an outstanding event that is prominently marked in Swiss history books. In 1937, however, the mighty employers' association of the machine and metal industry and all major labor unions signed a peace treat in which they agreed to handle dis agreements in good faith, to accept a formal multistage procedure of conflict resolution, and to firmly exclude strikes. This peace treaty, made in a time of economic and political crisisFascist Italy to the south and Nazi Germany to the north and soon to the east, in Austria, and west, in France, as well-has been renewed ever since. If a company, a branch, or an industry was in trouble, the labor unions and the employers' association searched to reach a mutual agreement on how to share the burden.

In this spirit, there were many Swiss entrepreneurs who, during the economic depression following the oil crisis in 1973, suffered tremendous losses in trying to save the lives of their companies and to avoid layoffs. When Firestone announced its shutdown of its Swiss production plant in 1978 , putting 600 workers out of their jobs, this was perceived as a profit-obsessed American manage- ment decision lacking all social responsibility. Many headlines in the Swiss press were exceptionally harsh: "Firestone: Brutal End," "Brutal Stroke of the Pen," "Brutal Decision of Firestone," "More than 600 Workers out of Job," "The Firestone Shock," "Now the Workers Feel Cheated," "Fierce Fight for the Fire stone Jobs," "A Village Fights a US Giant!" "From Rage to Consterna tion." The labor unions called for a two-day strike; a demonstration in front of the plant was held by some 3000 people. The government inter vened in favor of the workers, and solidarity was expressed throughou the country, even by political partie who represented employers' interests.

What had happened? Firestone's tire factory in Pratteln was founded in 1935 and celebrated as the most modern tire factory of the world. Three-quarters of the shares wer owned by the Swiss family Dätwyle and one quarter by Firestone. In the late 1960 s and early 1970 s, the com petitiveness of the company declined partly because Firestone prohibited the licensed Swiss plant from export ing its tires to Holland and Belgium. As a consequence, in 1973 the family members sold their shares to Fire stone. Firestone, at the time known for its conservative management policies, committed several manage

1. All headlines were translated from German and French to English by the author Corresponding to the sequence of titles, the sources are Blick, 23 Mar. 1978; Solothurner Arbeiterzeitung, 24 Mar. 1978; Journal du Valais, 23 Mar. 1978; Der Bund, 23 Mar. 1978; Pratteler Anzeiger, 28 Mar. 1978; Bündner Zeitung, 23 Mar. 1978; TagesAnzeiger, 30 Mar 1978; Blick, 30 Mar. 1978; Journal du Valais, 24 Mar. 1978. rial mistakes, however; it was late to recognize the market shift to radial ply tires, kept a nonrational multiplicity of products, and even had to call back a vast number of sold tires. Facing a loss of market share, the company urged the workers and employees of the Pratteln plant to accept short-time work several times plus a general reduction of work time and wages and also reduced the workforce from 1600 to 837 within five years-firmly promising to keep the factory alive by these measures. But in 1978, the board in Akron, Ohio, decided to shut down the Pratteln plant, together with another one in Calgary and even one in Akron. The Swiss labor force, after all the sacrifices, felt betrayed. ${ }^{2}$

A brief economic analysis revealed the structural problems Firestone was facing

The radial-ply tires reduced the demand for bias-ply tires. Radials lasted twice as long and thus generated worldwide decline of demand leaving large overcapacities in the tire industry. In addition, the production costs in Switzerland had soared significantly; when the U.S. dollar began to float, the Swiss franc reached a hitherto unseen high, making imports cheap and exports expensive. Locally, however, things looked different: sales were good; stocks were low; and within the Fireston group, the Swiss plant still was leading in quality. A general consensus emerged that the factory could be saved, be it by help of the government as the political left requested or by structural reorganization as the political right claimed. Solidarity was

2. Neue Zürcher Zeitung, 12 Apr. 1978. 
expressed by all the political parties, by the members of the parliament and the government of the state Basel-Land, and even by the federal secretary for economic affairs.

Then an event unique in Swiss economic history happened. Adelega tion of high-ranking political representatives-two members of the state government, a federal expert in economic affairs, and the Swiss ambassador to Washington-traveled to Akron to present their views on the economic situation and a proposal of measures by which Firestone could save the Swiss plant. American business executives are said to dislike government representatives. Accordingly, Firestone received the Swiss delegation only by members of the second and third rank. The Swiss felt insulted. The Americans, on the other hand, were reportedly quite puzzled about the vehement reaction in Switzerland; in America layoffs happened all the time. ${ }^{3}$

Firestone stayed with its original conclusion and shut down the Pratteln plant. And criticism stayed with Firestone. Two well-known German newsmagazines, Die Zeit and Der Spiegel, reported the case under the headlines "Exploited and Betrayed" and "Falsehood and Deceit." "The human being is of no value to these Americans. To them, we are only numbers," Die. Zeit quoted one worker as saying. "Hire and fire, in the United States the order of the day, is considered by the Swiss like the raging of a bull in a china shop." Indeed, the Swiss consensus con-

3. Ibid.; ibid., 14 Apr. 1978. 1978.

3. Thid., 16id., 14 Apr. 1978 . Spiegel, 5 Jun cerned above all the culturally inadequate, non-Swiss, American management style, which just ignored the social partnership the Swiss had practiced for the past forty years. The Swiss resented the fact that all the important Firestone decisions were made in Akron, far away from the place where they were to be implemented; they were neither based on local knowledge nor discussed with the local management and workforce. The shutdown was announced as a fait accompli; even the American top manager of Firestone Switzerland insisted he was surprised by the decision in Akron.

But the same top manager refused to reveal the crucial financial figures. This stirred up considerable suspicion, as wages and salaries had been higher and profits substantial during the Dätwyler era. ${ }^{5}$ One member of parliament concluded, "Foreign corporations acquire companies in order to shut them down. The production is dislocated to those places with the fewest social obligations. American bosses, too, shall not treat their employees like this, for we are no banana republic."6 Only five days later Firestone announced a multi-milliondollar project in Thailand to increase the production capacity of its Thai subsidiary.

\section{SWISSAIR DISLOCATES} WORK TO BOMBAY: THE SITUATION 15 YEARS LATER

Thirteen years after the Firestone layoffs, Swissair announced it was moving its revenue accounting de-

5. TagesAnzeiger, 30 Mar. 1978.

7. Neue Zürcher Zeitung, 19 Apr. 1978 partment to Bombay, India, costing 150 jobs and saving Fr8 million. This measure, part of the general revenue improvement program called Move, was implemented within three years. Although the company attempted to accomplish it with "natural leaves" and internal transfers of the persons concerned, dismissals were inevitable. For those affected, a "social plan" was worked out together with the employees' union. Financially, the transfer paid off well for Swissair: in Bombay, it is easy to find qualified people, and they cost only 10 percent-including 35 percent social costs-of what personnel cost in Switzerland. ${ }^{8}$

At the beginning of the $1990 \mathrm{~s}$, airline companies found themselves in their most severe crisis ever; they lost within two years what they had earned in two decades. In 1991, they were struck by the gulf war; in 1992 the price war began due to worldwide overcapacities. As this price war continues, Swissair has been attempting to remain a global carrier by a thorough organizational restructuring. In 1992, 40 percent of the total costs were personnel costs; therefore the reduc tion of personnel was a major source of cutting costs. And it still is; in the summer of 1995, Swissair announced that it would reduce its workforce by another 1600 jobs by $1997 .^{9}$

Compared to the Firestone shutdown, the reaction was extremel moderate. The dislocation of work to Bombay and the job reduction between 1991 and 1993 was met with comment by the employees' union

8. Ibid., 11 July 1991; ibid., 10 Aug. 1993 9. Ibid., 19 Aug. 1992; ibid., 20 Aug. 1992; ibid., 14 Sept. 1995.
VPOD, that "the future of the company is endangered by making the personnel bleed to death."10 Following the announcement of 1995, the mayor of the city of Kloten, where Swissair is the biggest employer, said he was "stunned" by the extent of the reduction, while the spokesman of the Aeropers, the association of cockpit personnel, stated that they had expected this development but think that "the board is saving the company to death." VPOD called the reduction "unacceptable" and "irresponsible" and protested the procedure; like Firestone, Swissair did not invite the unions to participate in the preparation of this decision, which was, accord ing to a union spokesman, "against the rules." 11

Certainly, a sudden shutdown of a production plant causes higher shock waves than does a transfer of work or a reduction of jobs that takes place over a two-year period. The dismissals at Swissair have been embedded in a broader strategy that relied on natural leaves, fostered early retirement, and allowed for internal dis placements. And, in contrast to Firestone, Swissair has offered from the outset to work out a so-called social plan together with the unions to reduce the hardships of dismissal. In addition, it created a so-called transfer organization (outplacement service), which offers counseling, training, and further education to the persons concerned. But Swissair's traditional role as a "model employer" in the country seems to belong to the past. $^{12}$

10. Ibid., 20 Oct. 1992.

11. Ibid., 14 Sept. 1995

12. Ibid. 


\section{AN AMERICANIZATION}

OF SWITZERLAND?

In my view, the differences between the Firestone and the Swissair cases cannot account sufficiently for the difference in the reactions of the Swiss public. The two cases were not selected at random. Rather, they symbolize a major change in Switzerland: people are getting used to the fact that their national economy, too is affected quickly and unpredictably by the whirlwinds of the world economy; that their country, too, is hit by layoffs and unemployment; and that Swiss corporations, too, dislocate work to Third World countries in order to survive. What in the case of Firestone was considered as a brutal and ruthless American style of management is becoming common Swiss practice. Swissair is by no means the only Swiss company that could be cited, but, as the national flag carrier and a traditional model employer, it certainly is the most symbolic of the trend.

Besides the turbulent changes in the world economy and the global political system, notably the disintegration of the Communist bloc in Eastern Europe, it is above all the emergence of visible unemployement that has formed a new vista on economic matters. Between World War II and the mid-1970s, unemployment in Switzerland was plainly nonexistent, at least in the public mind; the official figure fluctuated around 0.3 percent. In 1990, it soared to 0.65 percent, and then, within four years, it hit a record high of 4.5 percent

Of course, these figures do not represent the actual unemployment but only the number of reported unem- ployed. Besides the increased pressure of the world economy on local corporations, they also represent a particular change in mentality: unemployment now is considered to be a fact, and to be unemployed has become a legitimate status. Until the mid-1970s, to be unemployed was considered to be a shame, expressing a lack of motivation to work. "Everybody who wants to work can find work" was the general saying. Thus. many Swiss were too proud or ashamed to report themselves as unemployed to public authorities. There was a tendency of employers to first dismiss women and save the jobs for men-based on the traditional family model that men have to support a family while (married) women earn only pocket money. Moreover, many women just returned to their households when they lost their jobs and never showed up in the statistics. This was one factor that held the official figures low. The second was that, other than women, it was foreigners who lost their jobs, and they then either were expelled or returned voluntarily to their home countries. This way, Swiss unemployment was partly exported and showed up in the statistics of other countries, above all those of southern Europe.

In the face of the recession following the oil crisis, Switzerland introduced mandatory unemployment insurance in 1977. Before, the voluntary insurance had covered less than 50 percent of the unemployed; in earlier recessions, it had covered only about 20 percent. The general insurance evoked new behaviors and attitudes. To get unemployment benefits, many more unemployed persons now reported to public authorities, and many more foreigners stayed in the country. This made the unemployment rate soar, and the higher it became, the more it felt legitimate to report as unemployed. Undoubtedly, these new behaviors helped make the official statistics more representative of the actual unemployment rate. Thus it can be argued that unemployment in Switzerland has not really increased but has only become more visible. ${ }^{13}$

The general public, however, is hardly inclined to view the soaring unemployment rate as a statistical artifact but rather perceives it as a pure fact. Also alarming are the front-page news stories about new layoffs, new restructurings implying a reduction of the workforce, and new dismissals. The Swiss economy is obviously under increasing pressure and seems to be losing ground in international competition. Being pragmatic, the Swiss view this development as a challenge, one that may be frightening but that clearly makes further rationalization, structural adaptation, and new technological and social innovations inevitable. Like oth-

13. For a detailed economic discussion of this explanation, see Niklaus Blatter, "Arbeitslosigkeit: Tatbestände, Erklärungen Lösungsansätze," Forum Helveticum, 6:8-27 Lösungsansätze," Forum Helveticum, 6:8-27
(1995); Hans Schmid and Eckehard F. Rosenbaum, Arbeitslosigkeit und Arbeitslosenversicherung aus ökonomischer Sicht (Bern: Paul Haupt, 1995). For a comparison with other European states, see Hans Schmid, Peter Füglistaller, and Marcela Fuglistaller, and Marcela Hohl, Vollbeschaftigungspolitik: Der Wille zum Erfol (Bern: Paul Haupt, 1993). For an analysis of unemployment in Switzerland and economic and social remedies, see Hans Schmid, "Arbeitslosigkeit in der Schweiz: Diagnose und Ausblick," Forum Helveticum, 6:43-63 (1995). ers, Swiss corporations have clearly adopted the strategy of global sourcing and moving their production plants away from Switzerland to markets abroad. And they openly admit it ${ }^{14}$ without stirring up social unrest as Firestone did. In this sense, an Americanization is taking place: social responsibility and solidarity are being challenged more and more and often are being replaced by a pervasive economic rationality. The progressing globalization of the world economy will continually increase this trend, making the competition even harder and the pressure to rationalize even stronger.

\section{NEW FORMS OF SOLIDARITY:} THE VW SOLUTION

In the middle of this general trend that is taking place in all Western European countries, Volkswagen Corporation (VW) in Germany has put forward an alternative: instead of firing people, it introduced the fourday workweek in 1993. Naturally, this move gained a lot of publicity. Never before had a big corporation reduced work time to such an extent in order to redistribute work and avoid mass dismissals. In the press, the so-called VW solution was praised as an act of solidarity between management and the workforce, as a sign of social responsibility by a big corporation, and as proof that economic difficulties can be

14. For example, the personnel manager of the Swiss-Swedish corporation ABB. See Ren A. Lichtsteiner, "Neue Arbeitsplätze schaffen und Arbeitslosigkeit vermeiden: Lösungsansätze aus der Sicht einer grossen Arbeitgeberin," Forum Helveticum, 6:75-81 (1995). 
mastered without causing mass unemployment. ${ }^{15}$

The reasons for the economic problems were clearly visible. The car industry, like the tire industry in the 1970s (as shown by the Firestone case) or the airline business in the 1990s (as shown by the Swissair case), was struck by large overcapacities. In the mid-1990s, the worldwide production potential amounts to about 40 million cars annually, while less than 30 million are sold per year. VW already reduced its workforce from 130,000 in the 1980 s to 100,000 in 1993, promoting voluntary leaves via early retirement at the age of 55 . But in 1993 a further reduction of another 30,000 people seemed necessary. A cost reduction of 25 percent was considered to be inevitable, as VW had fallen far behind foreignabove all, Japanese - competitors.

The car industry, the heart of industry in the twentieth century, still is a paradigmatic example for rationalization. In the 1920s, Henry Ford realized a technical version of what Frederick Taylor had proposed in his "scientific management." It was copied by all of Ford's competitors. In the 1980s, the new managerial revolution took place, again in the auto in-

15. For the specifics of the VW solution, see Peter Hartz, Jeder Arbeitsplatz hat ein Gesicht: Die Volkswagen-Lösung (Frankfurt: Campus, 1994); Peter Haase and Thomas Kuhn, "Neue Arbeitszeitmodelle bei der Volkswagen AG-innovative Ansätze für mehr Wettbewerbsfähigkeit und wider di Wetthor Manaits Management, ed. R. Wunderer and T. Kuhn (Neuwied: Luchterhand, 1995). For the diverse reactions in the press, see Volkswagen Corporation, "Das VW-Modell der Vier-Tage-Woche im Spiegel der öffentlichen Meinung" (Manuscript, [1994]) dustry. It occurred first in Japan, with buzzwords such as "just-in-time production," "lean management," and "simultaneous engineering," and then in the United States with "total quality management," "business reengineering," and so on. ${ }^{16} \mathrm{VW}$ is still in the process of discussing and implementing these-as well as its own-new management concepts. To pair them with adequate behavior the personnel division set the strategic goal of developing "multifunctional, mobile, entrepreneurial and human workers and employees."17 These attributes are set to become the selection criteria for the future workforce.

Meanwhile, the VW solution builds on solidarity with three pillars. The first, the four-day workweek - that is, the reduction of the weekly work time from 36 to 28.8 hours and a corresponding reduction of wages and salaries-was introduced for everybody, including the top management and the board members. That means that even those in positions with much responsibility, working 50 or 70 hours a week, had to accept substantial pay reductions. The second pillar is the introduction of block times. Under this arrangement, each worker or employee may interrupt work for three or more months per year while staying in a regular contract. Block times suit primarily singles and younger people and should be used for study and

16. James P. Womack, Daniel T. Jones, and Daniel Roos, The Machine That Changed the World (New York: Macmillan, 1990).

17. In German, all these words begin with an " $\mathrm{M}$ ": "multifunktional, mobil, mitgestaltend menschlich." Therefore the concept is called the "M4 employee." training. To support this, VW has founded a coaching (consulting) company.

The third pillar may be the most peculiar: the relay race (Stafette) The relay race is a plan to distribute work among different age groups. Young people after apprenticeship may work 20 hours a week; after 24 months, they may work 24 hours; and after 42 months, they may work the full 28.8 hours of the four-day workweek. Similarly, people at the age of 56 who are not retiring are obliged to reduce their weekly work time by 4 hours and to receive less pay accord ingly. At 60 years of age, they must drop another 4 hours a week, or 2 months a year. The idea behind thi is a contract between the generations: younger and older people step back in favor of those who need work and money most, middle-aged people with families. As there are many families whose grandparents, parents, and children work at VW, this generation contract can often be trans posed directly into family terms, as solidarity between family members.

Can this new approach serve as a model for the future? There is a personal, an organizational, and an economic level to consider. So far, only the four-day workweek has been implemented. Two years later, the ma jority of the workforce still praises it as an act of solidarity that is "typically VW" (in the good sense). No surprise: every third or fourth person would have been personally hit by a mass dismissal without it. And as the average wage per month of a VW worker was DM4500 (\$3250) compared to the DM3500 $(\$ 2500)$ that is the average in the metal industry, they were still better off after the 20 percent work and wage reduction than were most of their colleagues. Many of those in key positions who work a lot of overtime, however, feel rather exploited by the new regulations.

On the organizational level, the four-day workweek for everybody causes a lot of problems. One top manager puts it this way: as a rule of thumb, the four-day workweek is suitable for production-to produce less, people work less-and maybe as a means to reduce the fat in the administrative overhead, but in many areas (development, sales, marketing, financial services) work reduction is fatal. Furthermore, the fourday workweek requires a huge amount of coordinating work, as the company is run for five days a week with people who are there for only four days. Even in small units, more than 150 different work-time models have been developed. On the economic level, experts note that the four-day workweek increases the costs of each work unit instead of reducing them, prevents conventional economic structures from necessary adaptations, and endangers Germany's overall competitiveness. ${ }^{18}$ Indeed, the VW solution is probably only a provisional solution. Maybe the company's board simply had to agree to it. In the big corporations in Germany, half of the members of the supervisory committee are by law representatives of the workers and employees, while the other half represent the shareholders. At VW, the Betriebsrat (works council) and the unions have for historical reasons always been stronger than they have 18. Personal interviews by the author. 
at other corporations. The biggest shareholder, the state of Lower Saxony, which owns 20 percent of the shares, is represented by the Social Democratic governor. Other corporations have clearly signaled that they are not willing to copy the VW model. But even within VW, the fundamental conflict may be just postponed. The radical cost cutting and rationalization measures within the company will drastically increase work productivity. The next model of the popular car Golf, due out in 1997, will be produced in only 24 hours of work per car, compared with 38 hours now. Unless the market will allow for many more sales, the workforce or its work time has to be reduced significantly again by 1998 . The union leaders of IG-Metall predict they will go on fighting for job security for all, while VW's chief executive officer, Ferdinand Piëch, threatens to join the great German corporate flight abroad. ${ }^{19}$ Whether the company will be able to avoid layoffs and dislocations and proceed with its solidarity pact as it moves into the next century remains to be seen.

THE ONGOING TENSION BETWEEN MODERNIZATION

AND NATIONAL CULTURES

Let us now broaden the scope. What are the prospects of work in the future? What will the twenty-first century look like? Will there be work for everybody who is willing to work? Or will work become a scarce good, reserved for privileged people? For nearly two decades, there has been a

19. See Bill Powell, "Germany's Angry Autoworkers," Newsweek International, 11 Sept. 1995, p. 37. heated international debate in Europe on this issue ${ }^{20}$ One group of scholars argues that technological rationalization and new management techniques increasingly wipe away jobs, continually diminishing the number of jobs in relation to the potential labor force. The new jobs will not balance the number of jobs that are lost, and more and more people will be pushed out of the economic system. Moreover, this will happen forever, without a return ticket. The future society will be a "two-thirds society"; there will be work left for only two-thirds of the population. The protagonists of this theory call for a new distribution of work by shortening the work time of each person. This would be a just solution and put everyone, they contend, back in a job. Many representatives of labor unions and of leftist political parties adhere to this view.

Another group of scholars reject this analysis firmly. They repudiate the underlying assumption that a general saturation is being reached, and they assure us that the economy will create enough jobs for everyone if the general frame conditions are modeled adequately. They explain the steady rate of unemployment of 10 percent and more in many industrialized states in two ways: (1) as a mismatch of demand and supply of labor concerning qualifications and regions and (2) as a result of the welfare state, which reduces the mobility

20. For a recent renewal of the debate, see Christian Lutz, "Unsere Zukunft-eine Zweidrittelsgesellschaft?" Neue Zürcher Zeitung, 14-15 May 1994, p. 23; Thomas A. Becker "Zukunft der Arbeit-nur für Akrobaten? Argumentationsdefizite des Szenariums Zweidrit telsgesellschaft," ibid., 2-3 Sept. 1995, p. 17. of people. In such a context, the shortening of work time would not distribute work more justly among the population but, worse, would reduce general wealth. Many managers of big corporations and other proponents of the upper-middle class support this view.

This discussion is likely to go on far into the twenty-first century. In the social market economies of Western Europe, the long-term unemployment rate makes the first group call for a redistribution of work, while the second blames the existing political and legal restrictions as causal factors and demands deregulation. Will this debate result in a political stalemate, or will global competition advance economic rationality at the expense of social responsibility and solidarity, as I proposed in the case of Switzerland?

A new modernization theory provides a suitable framework to discuss this in more depth. According to Peter Gross, ${ }^{21}$ modernity is advanced by three core processes: (1) "optioning," or the creation of more and more options; (2) detraditionalization, or the erosion of traditions; and (3) individualization. Modern societies create more and more options, be they goods or services, lifestyles or worldviews. At the same time, traditions lose their binding meaning, their collective obligation, and become one option among others. The joy and burden of choosing between options stays with the individual who has to make up his or her mind. The traditional guideposts have vanished; to orient oneself in a pluralistic and

21. Peter Gross, Die Multioptionsgesellschaft (Frankfurt am Main: Suhrkamp, 1995). fast-changing society with multiple life-worlds has become a lonely task. This trend can be illustrated with many examples. The traditional family, for instance, has become just one among many other ways of life. Divorces shatter the idea of lifelong relationships, more and more people live life as singles or just engage in partnerships-on-time, and in some states even homosexuals may get married now. The same pluralism applies to work. The conventional ideal of monogamous work, that is, of learning just one occupation or profession and staying loyal to the same corporation for a lifetime, as was common practice in Europe, gives way to polygamous work, to changing professions, jobs, and employers. ${ }^{22}$ This growing pluralism in almost every area of the life-world opens up a lot of opportunities but makes people prone to crises of orientation.

According to Gross, these interlinked core processes have a tremendous power in Western societies and are hardly stoppable. If this is true, Western Europe will become more and more Americanized; the proclaimed unity of a national culture will dissolve into multiple cultural milieus as a consequence of pluralism as well as immigration, and the traditional values of solidarity will give way to a pervasive individualism. In regard to the debate on the distribution of work, this would imply that the forces of deregulation in the long run will be stronger than the concepts of solidarity. If the trend in a deregulated economy should go to-

22. Compare Peter Gross, "Abschied von der monogamen Arbeit," gdi-Impuls, vol. 3 (1995). 
ward a two-thirds society or anything like it, we would have to redefine work; a political solution addressing how to sustain the jobless one-third economically would have to be found as would a way in which they could make their lives count in activities of a sort beyond the economic definition of work. ${ }^{23}$

Predictions in social sciences have a problematic status, however. Using the framework of Gross, it proves to be of great sociological interest to empirically study the multiplicity of movements and their honored value systems, Many of them are committed to stop the process of detraditionalization. As abortion evoked the prolife movement, the dissolution of the family evoked the pro-family movement. For an example of the outlook in Europe, Switzerland is a promising place to study such movements; a democratic society where people vote on substantial matters is a fine seismograph of what people think and feel. For Switzerland, the most important event in the 1990s was, no doubt, the vote on whether to join the European Economic Area-not the European Union, which would have been far more dramatic. The question was whether the Swiss would agree to a free trade of goods, services, capital, and people among the West European states. The outcome of the vote in 1992 was nearly half and half, with a slight majority against the treaty. While the French Swiss were clearly in favor of the agreement, a majority

23. Compare Thomas S. Eberle, "Wenn uns die Arbeit ausgeht: Ueber die gesellschaftliche Bedeutung der Arbeit," Pro Infirmis, 50(4): 3-9 (1991); H. Hoffmann and D. Kramer, eds., Arbeit ohne Sinn? Sinn ohne Arbeit? (Weinheim: Beltz athenäum, 1994). of German Swiss voted it down. The issue caused a schism in the country between those willing to further integrate into Europe and those who fear that Switzerland would lose its identity and become a pawn of the big European states.

Thus my former thesis that the Swiss get used to tough Americanstyle management and to the hard reality of economic laws in the world society has to be differentiated. About half of the voting population wants to preserve the historically grown, traditional structures of economy and society. They fear that a free market with Western Europe would destroy what is dear to them. Could the small businesses of the middle class survive against the capitalist strategies of the transnational corporations? Without state subsidies, could the farmers still have cows on the meadows? Could cheese still be produced in Switzerland if production costs are much lower in the Netherlands? What if even more immigrants were entering the country, at a time when already more than 19 percent of the population consists of foreigners, nearly three times as much as in Germany or France? ${ }^{24}$ Swiss culture, these voters are convinced, would fall apart.

Many economic experts favor an integration, while others oppose it. Both sides argue that the country would fare better economically. But the core issue is not wealth but values and emotions. Alpine herdsmen with alphorns, cows on the mountains

24. Swiss companies attracted many unqualified workers from abroad to keep thei costs low while not taking into account the social costs of cultural assimilation. with cowbells, and Swiss cheese of many sorts represent crucial symbols of national identity. They are not just symbols or stories; they are a lived reality, if only by a minority. In any case, they are not just a Disneyland financed by the tourism industry. There are plenty of additional local particularities that seem to be threatened by the mechanisms of unbound economic laws in a free international market, particularities that make people feel at home.

This schism is found all over Europe. No European government ever cared to ask their people whether or not they wanted to join the Common Market and the European Union. When Denmark and France finally took a vote on the Maastricht contract, the outcome was nearly half and half, too. All over Europe, there is a tension between national or local culture and economic union. This is evidenced in many instances: in the multiple special arrangements within the European Union, in the difficulty in finding a common policy toward the civil war in the Balkans, and in the discussions of people in everyday life. In addition, there is a fundamental tension in Europe between national culture and modernization, quite in contrast to the case of the United States. This schism is likely to continue far into the twentyfirst century. That means that the legitimating basis of each serious question and decision remains fragile. Modernization may progress but is never safe from backlashes as dramatic as the "ethnic cleansing" in former Yugoslavia. Work dislocation policies of European corporations must always be seen in the context of this basic tension and will always have to find some sort of local, temporary compromise. 


\section{THE ANNALS}

of The American Academy of Political and Social Science

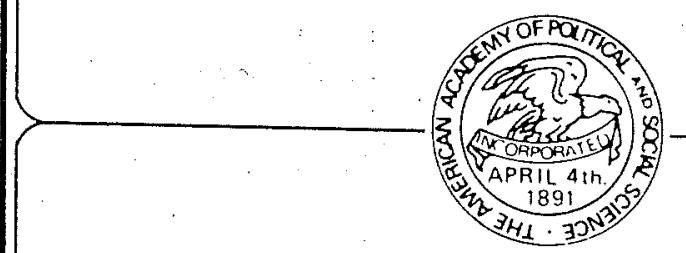

ALAN W. HESTON, Editor

NEUL A. WEINER, Assistant Editor

\section{FORTHCOMING}

CHALLENGES IN RISK ASSESSMENT AND RISK MANAGEMENT

Special Editors: Howard Kunreuther and Paul Slovic

Volume 545

\section{THE MEDIA AND POLITICS}

Volume 546 Special Editor: Kathleen Hall Jamieson

THE FUTURE OF HONG KONG Special Editor: Max J. Skidmore

Volume 547

See page 2 for information on Academy membership and purchase of single volumes of The Annals

\section{CONTENTS}

PREFACE,

\section{DEFINING THE CHALLENGE}

A NEW SOCLAL CONTRACT ................. Jeremy Rifkin 16

JOBS: NEW CHALLENGES, NEW RESPONSES ...... Sumner M. Rosen 27 HUMAN CAPITAL DEVELOPMENT:

AMERICA'S GREATEST CHALLENGE Theodore Hershberg 43

REFINING THE CHALLENGE

HIGH TECHNOLOGY AND WORK TOMORROW ...... Stanley Aronowitz and William DiFazio

SERVICE WORKERS: HUMAN RESOURCES

OR LABOR COSTS?

Barbara A. Gutek

ASSESSING ONGOING REFORMS

THE GERMAN APPRENTICESHIP SYSTEM:

LESSONS FOR AUSTIN, TEXAS ............... Robert W. Glover THE END OF HAWAII'S PLANTATIONS:

BACK TO THE FUTURE? $\ldots \ldots \ldots \ldots \ldots \ldots \ldots$ Lawrence W. Boyd, $J r$.

DISLOCATION POLICIES IN THE USA:

WHAT SHOULD WE BE DOING? . . . . . Ross Koppel and Alice Hoffman 111

DISLOCATION POLICIES IN WESTERN EUROPE

PAST, PRESENT, AND FUTURE ............ Thomas Samuel Eberle 127

EMPLOYMENT FLEXIBILITY AND

JOBLESSNESS IN LOW-GROWTH

RESTRUCTURED JAPAN .......... Koji Taira and Solomon B. Levine 140 LOOKING BEYOND

REWORKING WORK: TOUGH TIMES AHEAD Joseph F. Coates 154 COMPUTERS DON'T KILL JOBS,

PEOPLE DO: TECHNOLOGY AND

POWER IN THE WORKPLACE. Charley Richardson 167

PERFORMING WORK WITHOUT DOING JOBS Daniel Marschall 180 THE EMPLOYMENT OF NEW ENDS: PLANNING

FOR PERMANENT UNEMPLOYMENT .............. David Macarov 191

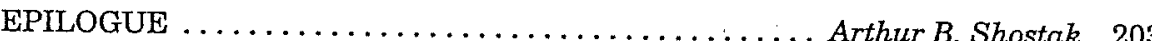
BOOK DEPARTMENT $\ldots \ldots \ldots \ldots \ldots \ldots \ldots \ldots \ldots \ldots \ldots \ldots \ldots, 206$

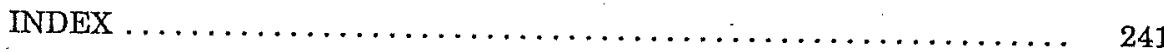




\section{THE AN NALS}

of The American Academy of Political and Social Science

ALAN W. HESTON, Editor NEIL A. WEINER, Assistant Editor

\section{IMPACTS OF CHANGING EMPLOYMENT} IF THE GOOD JOBS GO AWAY

Special Editor of this Volume ARTHUR B. SHOSTAK

Department of Psychology,

$$
\text { Sociology and }
$$

Anthropology

Drexel University

Philadelphia

Pennsylvania 